\title{
Carbon Dioxide Equivalent Emissions of Newly Developed Rice Varieties
}

\author{
Seied Mohsen Taghavi ${ }^{1,2}$, Teodoro C. Mendoza ${ }^{1}$, Bart Acero $\mathrm{Jr}^{2}$, Tao $\mathrm{Li}^{2}$, Sameer Ali Siddiq ${ }^{2,3}$, Jose Yorobe Jr. ${ }^{1}$, \\ Zhikang $\mathrm{Li}^{4} \&$ Jauhar $\mathrm{Ali}^{2}$ \\ ${ }^{1}$ College of Agriculture, University of the Philippines, Los Baños, Laguna, Philippines \\ ${ }^{2}$ International Rice Research Institute, Metro Manila, Philippines \\ ${ }^{3}$ University of Minnesota-Twin Cities, Minneapolis, USA \\ ${ }^{4}$ Chinese Academy of Agricultural Sciences, Beijing, China \\ Correspondence: Jauhar Ali, International Rice Research Institute, DAPO 7777, Metro Manila, Philippines. Tel: \\ 63-2-580-5600. E-mail: j.ali@irri.org
}

Received: January 8, $2017 \quad$ Accepted: March 6, $2017 \quad$ Online Published: April 15, 2017
doi:10.5539/jas.v9n5p107
URL: https://doi.org/10.5539/jas.v9n5p107

The research is financed by Bill \& Melinda Gates Foundation (BMGF).

\begin{abstract}
Breeding of rice varieties with low carbon dioxide equivalent $\left(\mathrm{CO}_{2} \mathrm{e}\right)$ emission is essential in reducing global greenhouse gas (GHG) emissions. In this study, we compared the gross $\mathrm{CO}_{2} \mathrm{e}$ emission of two newly developed green super rice (GSR) varieties with elite hybrids and nationally released farmer-cultivated varieties from production to post-production in the dry and wet seasons in Laguna, Philippines. The average gross $\mathrm{CO}_{2} \mathrm{e}$ emission was 17.9 tons $\mathrm{CO}_{2} \mathrm{e} \mathrm{ha}{ }^{-1}$ or 2.98 tons $\mathrm{CO}_{2} \mathrm{e}$ ton $^{-1}$ rice (production 82\%, post-production $18 \%$ ). Contributing to this total were soil emissions at $72 \%$, the use of chemicals at $5 \%$, burning of rice straw at $3 \%$, cooking at $12 \%$, and transportation at $5 \%$. The average social cost of carbon (SCC) per ton of rice was estimated at $\$ 119$. Increasing grain yield per unit area with shorter growth duration decreased $\mathrm{CO}_{2} \mathrm{e}$ emission of rice per unit of weight. Cultivation of rice varieties GSR8 and GSR2 emitted 37.0\% lower $\mathrm{CO}_{2} \mathrm{e}$ than the popular inbred varieties.
\end{abstract}

Keywords: carbon dioxide equivalent, carbon sequestration, soil emission, social cost of carbon, green super rice

\section{Introduction}

Rice $\mathrm{CO}_{2} \mathrm{e}$ emission is defined as the total set of GHG emissions from a unit area (ha) of a rice field and is calculated as carbon dioxide equivalent $\left(\mathrm{CO}_{2} \mathrm{e}\right)$. These GHGs include carbon dioxide $\left(\mathrm{CO}_{2}\right)$, methane $\left(\mathrm{CH}_{4}\right)$, and nitrous oxide $\left(\mathrm{N}_{2} \mathrm{O}\right) . \mathrm{CO}_{2} \mathrm{e}$ describes the potentials of a given $\mathrm{GHG}$ in contributing to global warming using the functional equivalent amount or concentration of $\mathrm{CO}_{2}$ as a reference.

By 2050 , global cereal production requirements are expected to grow by $70.0 \%$. Annual cereal production will increase to 3 billion tons from 2.1 billion tons in 2009, all of which need to be produced with reduced resources and without straining the environment (FAO, 2009) through the emission of greenhouse gases (GHG). In 2010, agriculture contributed $8.5 \mathrm{Gt} \mathrm{CO}_{2} \mathrm{e} \mathrm{yr}^{-1}$ of GHG emission (FAO, 2009, IPCC, 2007). The largest contributors to agricultural emissions are enteric fermentation (38\%), manure left on pasture (14\%), synthetic fertilizer (13\%), biomass burning (11\%), rice cultivation $(9 \%)$, manure management systems $(7 \%)$, organic soils $(5 \%)$, crop residues (3\%), and manure applied to cropland (2\%) (IPCC, 2007).

Rice production is often linked to $9 \%$ of the total GHG emissions in agriculture, which primarily occurs during the long periods of flooding in lowland rice cropping systems (Berners-Lee, 2010; IPCC, 2007). Lowland rice production emits the largest $\mathrm{CO}_{2} \mathrm{e}$ at $4.0 \mathrm{~kg} \mathrm{CO} \mathrm{e}$ per kilogram of rice. This is roughly four times higher $\mathrm{CO}_{2} \mathrm{e}$ than that from corn production, which is the next highest emitter (Berners-Lee, 2010). $\mathrm{CH}_{4}$, which is released during paddy rice production, makes up the principal component of the large $\mathrm{CO}_{2} \mathrm{e}$ emission of rice (Nalley et al., 2011). 
$\mathrm{CO}_{2}$ is emitted directly by applications of machines (from fuels and lubricants) and labor in both production and post-production levels. Production level includes all agricultural activities such as the application of inputs (seeds, chemicals, fertilizer) and irrigation, whereas post-production level includes transport, storage, drying, milling, retailing, and cooking. The production of machines, buildings, and inputs emits $\mathrm{CO}_{2}$ indirectly.

The lowland rice grown in flooded environments, the submerged parts of the plant, and the soil microorganisms respire anaerobically, leading to $\mathrm{CH}_{4}$ emission. In contrast, upland rice fields that are not flooded emit low amounts of $\mathrm{CH}_{4}$, estimated at $2 \mathrm{~g}$ per $\mathrm{kg}$ of rice (Kagi et al., 2010). A single mid-season drainage reduces $\mathrm{CH}_{4}$ emissions from 149 to 102 million tons of $\mathrm{C}$, bringing about a reduction of 138 million tons of $\mathrm{CO}_{2} \mathrm{e}$ (Wassmann et al., 2010).

$\mathrm{N}_{2} \mathrm{O}$ emission increases after paddy fields are drained, especially in soils where higher amounts of nitrogen $(\mathrm{N})$ fertilizer are applied. The seasonal emissions of $\mathrm{N}_{2} \mathrm{O}$ under continuously flooded rice fields were estimated at 0.002 ton $\mathrm{N}_{2} \mathrm{O}$ ha $^{-1}$ in the wet season (WS) and 0.003 ton $\mathrm{N}_{2} \mathrm{O}$ ha ${ }^{-1}$ in the dry season (DS) (Gaihre et al., 2014). A single mid-season drainage generally tends to decrease $\mathrm{CH}_{4}$ emissions up to $46.0 \%$ and increase $\mathrm{N}_{2} \mathrm{O}$ emissions up to $3.4 \%$ compared to continuously flooded paddy fields (Wassmann et al., 2010).

Among the viable approaches to reduce GHG emission in rice production is the use of high-yielding rice varieties that are more environment friendly as they require less inputs such as fertilizer, pesticides, and irrigation water, thereby emitting lower amounts of GHGs and helping improve environmental sustainability. Newly developed green super rice (GSR) varieties are resource use-efficient, especially on water and fertilizer, and they also possess key survival traits such as tolerance for drought, salinity, and flooding. This makes it important to see the relative performance of these GSR cultivars against high-yielding hybrid varieties and improved inbred rice varieties (Marcaida et al., 2014).

The high-yielding and short-duration GSR varieties also possess tolerance for multiple biotic (blast, bacterial leaf blight, and brown planthopper) and abiotic (less irrigation, drought, and low fertilizer inputs) stresses (Ali et al., 2013). GSR2 and GSR8 are drought-tolerant rice varieties (Marcaida et al., 2014; Ali et al., 2013) and are therefore highly suitable for alternate wetting and drying conditions.

The estimated cost of the damages caused by each ton of $\mathrm{CO}_{2}$ e emission released into the atmosphere is expressed as the social cost of carbon (SCC). The US government has endorsed a 'central' estimate of $\$ 40$ per ton of $\mathrm{CO}_{2}$ (Tollefson, 2015). The Philippines contributes a relatively smaller amount to the total global GHG emissions $(0.27 \%)$ as the total harvested area of rice production in 2013 was only $4.4 \mathrm{M}$ ha. However, $\mathrm{CO}_{2} \mathrm{e}$ emission left by rice crop cultivation has not been well documented especially in the Philippines (Mendoza et al., 2014).

This necessitates the development of rice varieties with lower $\mathrm{CO}_{2} \mathrm{e}$ emissions by directly increasing grain yield per unit area, especially under aerobic conditions, with shorter crop duration. In this study, we tried to determine the quantity of the $\mathrm{CO}_{2} \mathrm{e}$ emission for rice covering all operations and inputs from production to post-production as well as to identify the $\mathrm{CO}_{2} \mathrm{e}$ emission "hot spots" and corresponding SCC. Also, the study aimed to determine the $\mathrm{CO}_{2} \mathrm{e}$ emission of the newly bred GSR cultivars as compared to the $\mathrm{CO}_{2} \mathrm{e}$ emission of popular rice hybrid and elite inbred rice varieties.

\section{Materials and Methods}

\subsection{Data Collection}

This study was conducted during the wet season (May to October) of 2014 and dry season (November to March) of 2015 in seven different locations in the province of Laguna, Philippines. Four locations were in the town of Sta. Maria, latitude $14^{\circ} 50^{\prime} 9^{\prime \prime} \mathrm{N}$ longitude $121^{\circ} 43^{\prime} 29^{\prime \prime} \mathrm{E}$; two in the town of Majayjay, latitude $14^{\circ} 13^{\prime} 92^{\prime \prime} \mathrm{N}$ longitude $121^{\circ} 47^{\prime} 13^{\prime \prime} \mathrm{E}$; and one in the town of Famy, latitude $14^{\circ} 47^{\prime} 19^{\prime \prime} \mathrm{N}$ longitude $121^{\circ} 48^{\prime} 51^{\prime \prime} \mathrm{E}$. These locations were flood-free and the farmers had a good history of cooperation with the International Rice Research Institute (IRRI). Interviews with 77 rice farmers, who mostly used conventional farming systems (Table 1), and three rice millers at the different locations were undertaken to determine the $\mathrm{CO}_{2} \mathrm{e}$ emission for rice production (from land preparation to selling unmilled rice) and post-production (from transportation to drying and milling to cooking). The farmers were divided into two groups, GSR (those who planted the GSR variety seeds from IRRI) and non-GSR (those who planted their own variety seeds). Table 1 shows the distribution of farmers who participated in the study. 
Table 1. Distribution of farmers surveyed for the $\mathrm{CO}_{2}$ e emission study in seven rice-growing villages in Laguna, Philippines

\begin{tabular}{llll}
\hline Town & Barangay & Number of GSR farmers & Number of non- GSR farmers \\
\hline Sta. Maria & Bagumbayan & 5 & 5 \\
& Cambuja & 10 & 8 \\
& Coralan & 5 & 10 \\
& Talangka & 2 & 5 \\
\hline Majayjay & Munting Kawayan & 8 & 2 \\
\hline Famy & Oobi & 3 & 4 \\
\hline Total & Balitoc & 6 & 38 \\
\hline
\end{tabular}

The study focused on the quantification of $\mathrm{CO}_{2}$ e emission from the start of cultivation of two high-yielding, short-duration, irrigated GSR varieties. GSR2 (IR83142-B-19-B) is a variety tolerant of drought and low input, whereas GSR8 (GSR IR1-8-S6-S3-Y2) is a variety tolerant of multiple abiotic stresses such as drought, salinity, and flooding. Both are suitable for aerobic soils (Ali et al., 2013). The $\mathrm{CO}_{2} \mathrm{e}$ emission of their cultivation were compared with emission from the cultivation of three elite inbreds (PSBRC11, PSBRC18, and PSBRC216) and two hybrid rice cultivars (SL9 and SL7), which are normally planted by farmers. Both GSR cultivars were bred at the International Rice Research Institute (IRRI). A completely randomized design was used for the experimental plot layout for data on grain yield, growth duration (transplanting to harvesting), and $\mathrm{CO}_{2} \mathrm{e}$ emission in 77 farmers' fields in seven locations with three replicates per location in both the WS and DS. Each replicate plot comprises a crop cut area of $1 \mathrm{~m}^{2}(1 \mathrm{~m} \times 1 \mathrm{~m})$, which was selected randomly within the treatment plot of a given variety. There was no cropping calendar offered and the farmers were free to use their own cropping calendar.

The farmers were divided into two groups: GSR (those who planted the GSR varieties) and non-GSR (those who planted their own varieties). The surveys were done during two different stages of the rice growth season: at 6 weeks (or 42 days) after transplanting and at harvest time. The $\mathrm{CO}_{2} \mathrm{e}$ emission at the production level included the emissions from the production of inputs, the embedded energy of machines, labor, and diesel fuel and lubricant. The final grain yield and total above-ground harvested biomass weight were obtained during harvest. The $\mathrm{CO}_{2} \mathrm{e}$ emission at the post-production level included emissions from drying (sun drying/mechanical drying), milling, hulling, storing, transporting, retailing, and cooking. It was estimated by taking the sum of all emissions of labor, machinery, and diesel fuel in each and every operation. The energy conversion coefficient for rice production (Table 2) was used to convert the collected data from the farmers' survey into energy, expressed as $\mathrm{MCal}$, into liter diesel oil equivalent (LDOE) and into $\mathrm{CO}_{2} \mathrm{e}$ emission. The $\mathrm{CO}_{2} \mathrm{e}$ of $\mathrm{CH}_{4}$ and $\mathrm{N}_{2} \mathrm{O}$ emission was estimated using methods described in previous studies carried out at IRRI (Gaihre et al., 2014), one of which involved a field experiment conducted during the 2010 WS and 2011 DS under irrigated conditions.

Table 2. The energy coefficients used for rice production

\begin{tabular}{|c|c|c|c|}
\hline Input & Unit & Energy MCal & Reference \\
\hline Labor & Hour & 0.58 & Ozkan et al. (2004) \\
\hline Machinery & $\mathrm{kg}$ & 15.7 & Traas et al. (2012) \\
\hline Diesel fuel & Liter & 11.4 & Pimentel et al. (1980) \\
\hline Gasoline & Liter & 10.14 & Pimentel et al. (2008) \\
\hline Electricity & $\mathrm{KWh}$ & 2.863 & Pimentel et al. (1980) \\
\hline Lubricant & Liter & 11.96 & EIA (Energy Information Administration) (2013) \\
\hline Fertilizer N & $\mathrm{kg}$ & 20.52 & McLaughlin et al. (2000) \\
\hline Fertilizer P & $\mathrm{kg}$ & 4.14 & Pimentel et al. (2006) \\
\hline Fertilizer K & $\mathrm{kg}$ & 3.26 & Pimentel et al. (2006) \\
\hline Seed & $\mathrm{kg}$ & 4.28 & Pimentel et al. (2006) \\
\hline Chemicals & $\mathrm{kg}$ & 100 & Pimentel et al. (2006) \\
\hline Dam & Season $\mathrm{ha}^{-1}$ & 220 & Taghavi et al. (2011) \\
\hline Canal & Season $\mathrm{ha}^{-1}$ & 258 & Taghavi et al. (2011) \\
\hline
\end{tabular}




\subsection{Data Analysis}

Analysis of variance (ANOVA) was carried out to test the significance across varieties in terms of grain yield, growth duration (from transplanting to harvesting), and $\mathrm{CO}_{2} \mathrm{e}$ emission from production to post-production. Tukey's Honest Significant Difference test, on the other hand, was used for pairwise mean comparison. Both tests uses $\alpha=0.05$ level of significance. All analyses were done using the Plant Breeding Tools (PBTools) software integrated in $\mathrm{R}$ statistical programming language. The statistical analysis of $\mathrm{CH}_{4}$ and $\mathrm{N}_{2} \mathrm{O}$ emission was estimated using previous studies carried out at IRRI during the 2010 WS and 2011 DS (Gaihre et al., 2014).

The net $\mathrm{CO}_{2} \mathrm{e}$ balance of rice production was estimated by taking the sum of the $\mathrm{CO}_{2}$ emissions from: (1) rice production to post-production, (2) $\mathrm{CH}_{4}$ and $\mathrm{N}_{2} \mathrm{O}$ gases, and (3) burning of rice straw, and then subtracting the carbon sequestration.

The formula used in estimating the net $\mathrm{CO}_{2}$ emissions are as follows (Equation 1):

$$
\mathrm{CO}_{2} e_{\mathrm{Net}}=\left(\mathrm{CO}_{2} e \mathrm{P}+\mathrm{CO}_{2} e \mathrm{Pp}+\mathrm{CO}_{2} e \mathrm{~S}+\mathrm{CO}_{2} e \mathrm{Sb}\right)-\mathrm{CO}_{2} e \mathrm{Se}
$$

Where, $\mathrm{CO}_{2} e_{\text {Net }}$ (ton) = net $\mathrm{CO}_{2}$ e emission of 1 ha unmilled rice; $\mathrm{CO}_{2} e P$ (ton) $=\mathrm{CO}_{2} \mathrm{e}$ emission from 1 ha of rice crop at production stage; $\mathrm{CO}_{2} e \mathrm{Pp}$ (ton) $=\mathrm{CO}_{2}$ e emission from 1 ha of rice crop at post-production stage; $\mathrm{CO}_{2} e \mathrm{~S}$ (ton) $=\mathrm{CO}_{2} \mathrm{e}$ of soil $\mathrm{CH}_{4}$ and $\mathrm{N}_{2} \mathrm{O}$ emitted from 1 ha of rice crop; $\mathrm{CO}_{2} e \mathrm{Sb}$ (ton) $=\mathrm{CO}_{2} \mathrm{e}$ emitted from burning the straw of 1 ha of rice crop; and $\mathrm{CO}_{2} e \mathrm{Se}$ (ton) = total amount of $\mathrm{CO}_{2}$ sequestrated in 1 ha of rice crop.

The collected data for $\mathrm{CO}_{2} \mathrm{e}$ from rice production to post-production were converted into energy expressed as MCal or conversion coefficient of energy (Table 2) and liter diesel oil equivalent (LDOE). The coefficient of MCal to LDOE is (11.4) ${ }^{-1}$. The $\mathrm{CO}_{2} \mathrm{e}$ emission was computed by multiplying the LDOE/unit input or operation by $3.98 \mathrm{~kg} \mathrm{CO}_{2} \mathrm{LDOE}^{-1}$. The $\mathrm{CO}_{2}$ emission from $1 \mathrm{~L}$ diesel oil in agriculture equals $3.94 \mathrm{~kg} \mathrm{CO}_{2} \mathrm{~L}^{-1}$ and is the sum of the direct $\left(3.71 \mathrm{~kg} \mathrm{CO}_{2} \mathrm{~L}^{-1}\right)$ and the indirect emissions $\left(0.23 \mathrm{~kg} \mathrm{CO}_{2} \mathrm{~L}^{-1}\right)$ (IPCC, 2006).

\subsection{1 $\mathrm{CO}_{2} \mathrm{e}$ Emission of Labor}

The coefficient of labor works duration to energy was $0.58 \mathrm{MCal} \mathrm{hr}^{-1}$. For the farmers' survey, the total hours of labor incurred for production and post-production of 1 ha rice (production: land preparation, seedling preparation, planting, agronomic management operations, and harvesting, and) and (post-production: sun-drying, milling, storing, transporting, retailing, and cooking) were estimated as follows (Equation 2):

$$
\mathrm{CO}_{2} \text { e } L=\frac{h r \times 0.58 \times 3.98}{11.4 \times 1000}
$$

Where, $\mathrm{CO}_{2} e L$ (ton): $=\mathrm{CO}_{2}$ e emission of labor; $h r=$ : Labor work duration in 1 ha rice field; $0.58=$ coefficient of labor to energy (MCal); 11.4 = coefficient of MCal to LDOE (li); 3.98 = coefficient of LDOE to $\mathrm{CO}_{2} \mathrm{e}(\mathrm{kg})$; $1,000=$ coefficient of kilogram to ton.

\subsection{2 $\mathrm{CO}_{2} \mathrm{e}$ Emission of Machinery}

The embedded energy (for manufacture, maintenance, and repair) of powered machinery per kilogram weight of machine is $15.7 \mathrm{MCal} \mathrm{kg}^{-1}$. The lifespan of machinery used in the estimate was 15 years (Traas, 2012). The collected data for rice farm and post-production machinery included machine capacity, weight of machine, and number of seasons per year.

The embedded energy of rice farm machinery for production and post-production of 1 ha rice per season was estimated as follows (Equation 3):

$$
\mathrm{CO}_{2} \text { e } M=\frac{W \times 15.7 \times 3.98}{L T \times S \times C \times 11.4 \times 1000}
$$

Where, $\mathrm{CO}_{2}$ e $M$ (ton) = $\mathrm{CO}_{2} \mathrm{e}$ emission of machinery; $W(\mathrm{~kg})=$ weight of machines; $L T$ (year) = lifespan of machine; $S=$ number of seasons per year; $C=$ capacity of machine (area where machine was used); $15.7=$ coefficient of machinery to energy (MCal); 11.4 = coefficient of MCal to LDOE (li); 3.98 = coefficient of LDOE to $\mathrm{CO}_{2} \mathrm{e}(\mathrm{kg}) ; 1,000=$ coefficient of kilogram to ton.

\subsection{3 $\mathrm{CO}_{2} \mathrm{e}$ Emission of Fuel, Electricity, and Lubricant}

Some cropping activities that included plowing, harrowing, threshing, and winnowing in production and milling, transporting, and cooking at post-production required diesel fuel, lubricant, and electricity. The estimated LPG consumption for cooking 1 ton of rice was about $86 \mathrm{~kg}$ (Anoopa et al., 2007) and the LPG energy value was estimated at $11.01 \mathrm{MCal} \mathrm{kg}^{-1}$. The energy consumed for cooking 1 ton of milled rice was estimated at 946.9 MCal. 


\subsection{4 $\mathrm{CO}_{2} \mathrm{e}$ Emission of Material Inputs}

The energy coefficient for the production and manufacture per unit of input is given in Table 2 . The energy value of inputs such as fertilizer, seeds, and chemicals for 1 ha rice was computed by simply multiplying the weight of each input to the corresponding energy coefficient.

\subsection{5 $\mathrm{CO}_{2} \mathrm{e}$ Emission of Storage}

Based on the minimum estimates of energy used for a low-rise flat building, the energy used for storage of products at room temperature is estimated as $0.006 \mathrm{MCal} \mathrm{M}^{-3}$ day $^{-1}$. Building lifespan is estimated to be about 50 years (Hastoe Housing Association, 2010). The volume of $1.0 \mathrm{~kg}$ paddy is 1.6 liters and the volume of $1.0 \mathrm{~kg}$ white rice is 1.1 liters (Rice Knowledge Bank, 2013). The energies used for the storage of 1 ton paddy and white rice were calculated at 0.009 and $0.007 \mathrm{MCal} \mathrm{t}^{-1} \mathrm{day}^{-1}$, respectively.

\subsubsection{Soil $\mathrm{CO}_{2} \mathrm{e}$ Emission}

$\mathrm{CH}_{4}$ and $\mathrm{N}_{2} \mathrm{O}$ emissions were measured using the closed chamber technique. The gas samples were taken from each chamber and were directly injected into the Gas Chromatograph with flame ionization detector (FID). The emission rates of $\mathrm{CH}_{4}$ and $\mathrm{N}_{2} \mathrm{O}$ were determined from the slope of the linear regression curves of $\mathrm{CH}_{4}$ and $\mathrm{N}_{2} \mathrm{O}$ concentrations against chamber closure time.

The average daily emissions of $\mathrm{CH}_{4}$ and $\mathrm{N}_{2} \mathrm{O}$ gases under continuously flooded rice fields were estimated at 4.08 $\mathrm{kg} \mathrm{CH}_{4} \mathrm{ha}^{-1} \mathrm{~d}^{-1}$ and $0.0175 \mathrm{~kg} \mathrm{~N}_{2} \mathrm{O} \mathrm{ha}^{-1} \mathrm{~d}^{-1}$, respectively, in the WS and $5.58 \mathrm{CH}_{4} \mathrm{ha}^{-1} \mathrm{~d}^{-1}$ and $0.0275 \mathrm{~kg} \mathrm{~N}_{2} \mathrm{O} \mathrm{ha}^{-1}$ $\mathrm{d}^{-1}$, respectively, in the DS (Gaihre et al., 2014). Single mid-season drainage generally tends to decrease $\mathrm{CH}_{4}$ emissions up to $46.0 \%$ and increase $\mathrm{N}_{2} \mathrm{O}$ emissions up to $3.4 \%$ as compared to continuously flooded paddy fields (Wassmann et al., 2010).

The $\mathrm{CO}_{2} \mathrm{e}$ of $\mathrm{CH}_{4}$ and $\mathrm{N}_{2} \mathrm{O}$ over 100 years is 25 and 298 times that of $\mathrm{CO}_{2}$, respectively (Cummins, 2006). The $\mathrm{CO}_{2} \mathrm{e}$ of $\mathrm{CH}_{4}$ and $\mathrm{N}_{2} \mathrm{O}$ emission from production of 1 ha rice was estimated using the following equation (Equation 4):

$$
C \mathrm{O}_{2} e S=\frac{\left(W_{\left(\mathrm{CH}_{4}\right)} \times G W P \times D\right)+\left(W_{\left(\mathrm{N}_{2} \mathrm{O}\right)} \times G W P \times D\right)}{1000}
$$

Where, $\mathrm{CO}_{2} e S$ (ton) = soil emission of 1 ha rice; $W_{\left(\mathrm{CH}_{4}\right)}(\mathrm{kg})=$ weight of $\mathrm{CH}_{4}$ emitted from 1 ha rice per day; $W_{(\mathrm{N} 20)}(\mathrm{kg})=$ weight of $\mathrm{N}_{2} \mathrm{O}$ emitted from 1 ha rice per day; $\mathrm{GWP}=$ global warming potential, $\mathrm{CH}_{4}=25$ and $\mathrm{N}_{2} \mathrm{O}=298 ; \mathrm{D}=$ number of days from transplanting to harvesting; $1,000=$ coefficient of kilogram to ton.

\subsection{7 $\mathrm{CO}_{2} \mathrm{e}$ Emission of Straw Burning}

GHG emissions from rice straw burning were measured using a combustion stove that had a vertical chimney that was connected to a chamber equipped with a fan to mix gases (Hossain \& Park, 2012). The gas samples were taken from the chamber and measured by directly injecting into the gas chromatograph with FID. The emission factors (EF) of $\mathrm{CH}_{4}$ and $\mathrm{N}_{2} \mathrm{O}$ per ton of dried burnt rice straw were estimated at 3 and $0.07 \mathrm{~kg}$, respectively (Chang et al. 2013). Only $90 \%$ of the straw was burned and $10 \%$ remained in the field (IPCC, 1997) The $\mathrm{CO}_{2} \mathrm{e}$ of $\mathrm{CH}_{4}$ and $\mathrm{N}_{2} \mathrm{O}$ emission from the burning of 1 ha rice straw was determined by using the following equation (Equation 5):

$$
\mathrm{CO}_{2} e \mathrm{Sb}=\frac{\left(E F_{\left(\mathrm{CH}_{4}\right)} \times W \times G W P \times 0.9\right)+\left(E F_{\left(\mathrm{N}_{2} \mathrm{O}\right)} \times W \times G W P \times 0.9\right)}{1000}
$$

Where, $\mathrm{CO}_{2} e \mathrm{Sb}\left(\right.$ ton $\left.\mathrm{ha}^{-1}\right)=\mathrm{CO}_{2} \mathrm{e}$ of $\mathrm{CH}_{4}$ or $\mathrm{N}_{2} \mathrm{O}$ from straw burning of 1 ha rice; $E F_{\left(\mathrm{CH}_{4}\right) \text { or }\left(\mathrm{N}_{2} \mathrm{O}\right)}=$ emission factor of $\mathrm{CH}_{4}$ or $\mathrm{N}_{2} \mathrm{O}(\mathrm{kg})$ from burning of 1 ton straw; $W$ (ton ha ${ }^{-1}$ ) = weight of straw that was burned (ton ha ${ }^{-1}$ ); $G W P=$ global warming potential, $\mathrm{CH}_{4}=25$ and $\mathrm{N}_{2} \mathrm{O}=298 ; 0.9=$ completely burnt straw; $1,000=$ coefficient of kilogram to ton.

\subsubsection{Carbon Sequestration in the Rice Field}

After harvest, the parts of the rice crop that are left in the field include (a) the dry root biomass, which is estimated using the root/shoot ratio with a range of 0.05 to 0.08 (Gowda et al., 2012), and an average of 0.035 (Suralta, 2015; Gowda et al., 2012) multiplied to the total above-ground dry biomass; (b) straw left uncut, which is calculated from the sampling of uncut straw per unit area $\left(1 \mathrm{~m}^{2}\right)$ expressed on a per hectare basis; and (c) $10 \%$ of the straw that was not fully burned (IPCC, 1997). Total carbon sequestration in the rice field is determined by using the following equation (Equation 6):

$$
\mathrm{CO}_{2} e \mathrm{Se}=\frac{(W r+W s) \times 0.4 \times 0.15 \times 3.7}{1000}
$$


Where, $\mathrm{CO}_{2} \mathrm{e} \mathrm{Se}$ (ton) is the total amount of $\mathrm{CO}_{2}$ sequestrated in the soil as soil organic matter; $W r\left(\mathrm{~kg} \mathrm{ha}{ }^{-1}\right)$ is the weight of root biomass $=0.035 \times$ above-ground biomass; $W_{S}\left(\mathrm{~kg} \mathrm{ha}^{-1}\right)=$ weight of the rice straw left uncut and unburnt after harvesting; $0.4=$ carbon content of rice dried straw (moisture content was 14\%); $0.15=$ humus-C part of soil organic matter after decomposition (Batjes, 1996); $3.7=\mathrm{CO}_{2} / \mathrm{C}$ conversion of the weight of $\mathrm{C}$ to $\mathrm{CO}_{2}$.

\subsection{Social Cost of Carbon (SCC)}

The US government has endorsed a 'central' estimate cost of $\$ 40$ per ton of $\mathrm{CO}_{2}$ (Tollefson, 2015). Using this toll on carbon, SCC was estimated by multiplying the carbon emitted by 1 ton rice to the cost of carbon at $\$ 40$ (Equation 7).

$$
\operatorname{SCC}(\$)=\mathrm{CF} \times \$ 40
$$

Where, $\mathrm{SCC}(\$)=$ social costs of $\mathrm{CO}_{2} \mathrm{e}$ per ton of rice production to post-production; $\mathrm{CO}_{2} \mathrm{e}($ ton) $)=\mathrm{CO}_{2}$ emission from 1 ton rice production to post-production.

\section{Results}

\subsection{Life Cycle Inventory (LCI)}

The life cycle inventories of farmers in Laguna, Philippines were obtained from surveys in the 2014 WS and 2015 DS. The farmers mostly used conventional farming systems (Table 3). The rice cultivation in Laguna, Philippines was limited to one cropping per season. The dry season was from early November to mid-December and harvest was on March. The wet season started in May and June, and cultivation finished by the end of October. Most of the farms were irrigated by canals and the farmer's calendar was managed by the National Irrigation Administration (NIA). Lowland rice production required a well-leveled field. Land preparation includes plowing and harrowing (by small tiller) and leveling (by buffalo). In mountainous regions, farmers were unable to use machines. During the dry season, water drainage occurred 3 to 4 times per season and some areas suffered from water deficit. During the wet season, farms were flooded for a whole season and few of the farms were affected by typhoon and submergence.

Urea and NPK were the most consumable fertilizer for Laguna rice farmers. About 3 to 4.4 liters of herbicide and insecticide in 2 to 3 applications were consumed per hectare. Farmers applied more fertilizer, pesticide, and seeds in the dry season than in the wet season (Table 3). Machinery use was limited to small machines such as tiller, thresher (carried by jeep,) and a small blower. This increased labor requirements at different stages of production to 581 hours per hectare. 
Table 3. Life cycle inventories (LCIs) of rice cropping per hectare during the 2014 wet and 2015 dry seasons

\begin{tabular}{|c|c|c|c|c|c|c|c|}
\hline & Unit & Land preparation & Seedling preparation & Planting & Crop Management & Harvest & Total \\
\hline \multicolumn{8}{|l|}{ Dry Season } \\
\hline Labor & $\mathrm{hr}$ & 118.3 & 54.7 & 82 & 85.2 & 241.39 & 581.6 \\
\hline Machine & $\mathrm{Mcal} / \mathrm{s}$ & 39 & & & & 15.6 & 54.6 \\
\hline Fuel & 1 & 194.6 & & & & 324.7 & 519.3 \\
\hline Lubricant & 1 & 15.07 & & & & 9.6 & 8.55 \\
\hline Seed & $\mathrm{kg}$ & & 55.3 & & & & 55.3 \\
\hline Fertilizer N & $\mathrm{kg}$ & & & & 114.6 & & 114.6 \\
\hline Fertilizer P & $\mathrm{kg}$ & & & & 20 & & 20 \\
\hline Fertilizer K & $\mathrm{kg}$ & & & & 17.9 & & 17.9 \\
\hline Pesticide & 1 & & & & 4.4 & & 4.4 \\
\hline Irrigation & $\mathrm{Mcal} / \mathrm{s}$ & & & & 148.5 & & 148.5 \\
\hline \multicolumn{8}{|l|}{ Wet Season } \\
\hline Labor & $\mathrm{hr}$ & 118.3 & 54.7 & 82 & 85.2 & 241.39 & 581.6 \\
\hline Machine & $\mathrm{Mcal} / \mathrm{s}$ & 39 & & & & 15.8 & 54.6 \\
\hline Fuel & 1 & 194.6 & & & & 324.7 & 519.3 \\
\hline Lubricant & 1 & 15.07 & & & & 9.6 & 24.6 \\
\hline Seed & $\mathrm{kg}$ & & 53 & & & & 53 \\
\hline Fertilizer N & $\mathrm{kg}$ & & & & 97.2 & & 97.2 \\
\hline Fertilizer P & $\mathrm{kg}$ & & & & 15.5 & & 15.5 \\
\hline Fertilizer K & $\mathrm{kg}$ & & & & 11.6 & & 11.6 \\
\hline Pesticide & 1 & & & & 3 & & 3 \\
\hline Irrigation & $\mathrm{Mcal} / \mathrm{s}$ & & & & 148.5 & & 148.5 \\
\hline
\end{tabular}

\section{2 $\mathrm{CO}_{2}$ e Emission Sources}

The average gross $\mathrm{CO}_{2} \mathrm{e}$ emission was estimated to be 17.9 tons $\mathrm{CO}_{2} \mathrm{e} \mathrm{ha}{ }^{-1}$, of which 14.6 tons $\mathrm{CO}_{2} \mathrm{e} \mathrm{ea}^{-1}$ is emitted from rice production $(82 \%)$ and 3.2 tons $\mathrm{CO}_{2} \mathrm{e} \mathrm{ha}^{-1}$ from post-production (18\%). Contributing to this total rice $\mathrm{CO}_{2} \mathrm{e}$ emission were soil emissions at 12.8 tons $\mathrm{CO}_{2} \mathrm{e} \mathrm{ha}^{-1}(72 \%)$, the use of fertilizers and pesticides at 0.9 ton $\mathrm{CO}_{2} \mathrm{e} \mathrm{ha}{ }^{-1}(5 \%)$, burning of rice straw at 0.5 ton $\mathrm{CO}_{2} \mathrm{e}$ ha ${ }^{-1}(3 \%)$, cooking at 2.1 tons $\mathrm{CO}_{2} \mathrm{e} \mathrm{e}^{-1}(12 \%)$, and transportation at 0.95 ton $\mathrm{CO}_{2} \mathrm{e} \mathrm{ha}^{-1}(5 \%)$ (Figure 1).

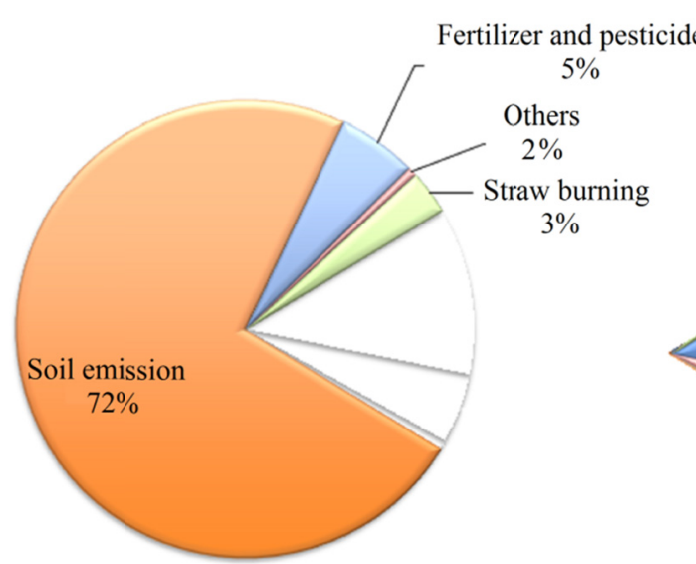

Production

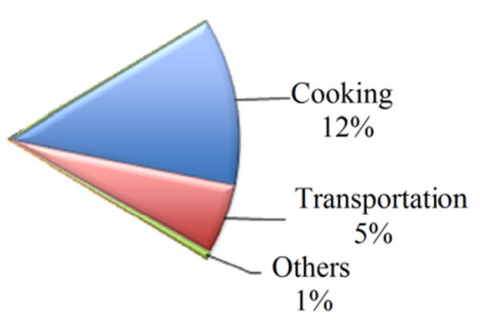

Post-production

Figure 1. The components of $\mathrm{CO}_{2} \mathrm{e}$ emission sources per unit area (ha) from production to post-production 


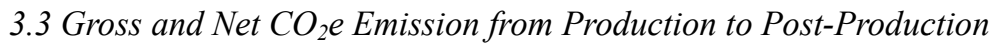

The net $\mathrm{CO}_{2} \mathrm{e}$ emissions were determined by subtracting the carbon sequestration from gross $\mathrm{CO}_{2} \mathrm{e}$ emissions. The gross $\mathrm{CO}_{2} \mathrm{e}$ emissions of the varieties from rice production to post-production in the DS (20.60 tons $\mathrm{CO}_{2}$ ha $^{-1}$ or 3.53 tons $\mathrm{CO}_{2}$ ton $^{-1}$ ) and WS (15.11 tons $\mathrm{CO}_{2} \mathrm{ha}^{-1}$ or 2.46 tons $\mathrm{CO}_{2}$ ton $^{-1}$ ) were significantly different ( $p<$ 0.001) (Figure 2). Carbon sequestration was equivalent to 0.8 and 0.9 ton $\mathrm{CO}_{2} \mathrm{ha}^{-1}$ in the DS and WS, respectively.

The gross $\mathrm{CO}_{2} \mathrm{e}$ emissions of all the varieties at production level in the DS and WS were significantly different $(p<0.001)$ and were estimated at 17.36 and 11.87 tons $\mathrm{CO}_{2}$ ha $^{-1}$, respectively. The average of post-production was 3.2 tons $\mathrm{CO}_{2}$ ha $^{-1}$ of unmilled rice (Figure 2).

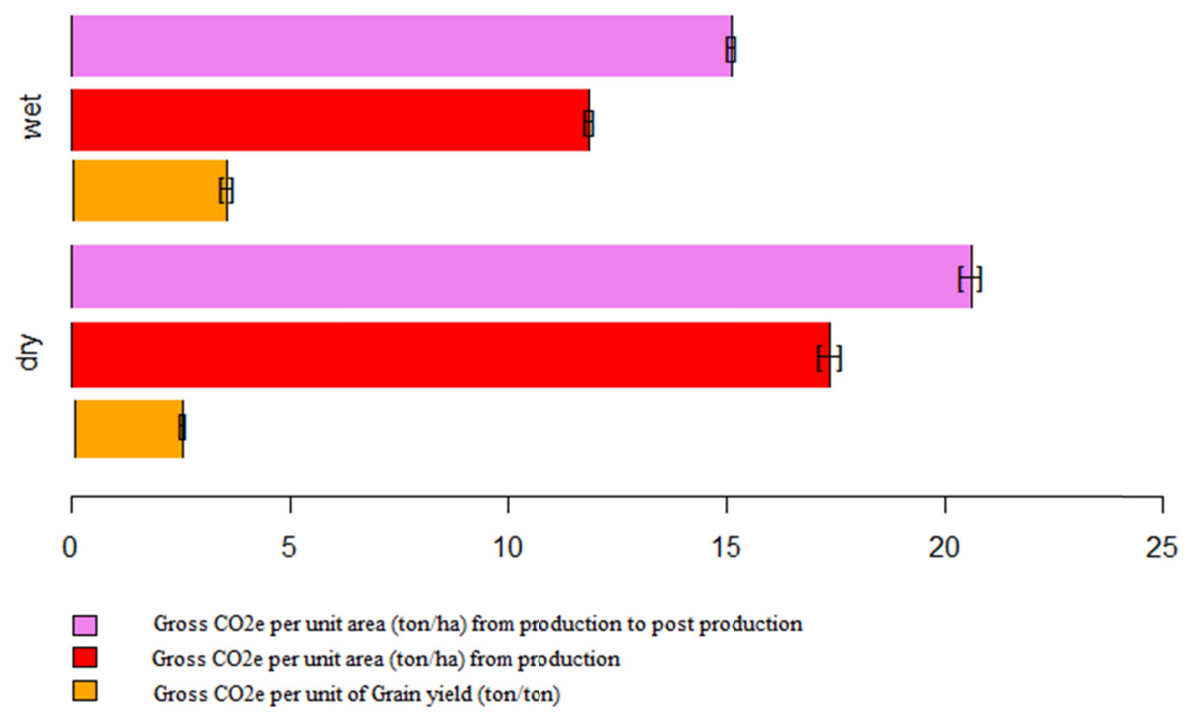

Figure 2. Relative gross $\mathrm{CO}_{2}$ emission of rice under the wet and dry seasons from production to post-production

\section{$3.4 \mathrm{CO}_{2}$ e Emission at Crop Production Level}

The $\mathrm{CO}_{2} \mathrm{e}$ emission of rice during the DS was 5.5 tons $\mathrm{CO}_{2} \mathrm{ha}^{-1}, 37 \%$ higher than in the WS. This was due to more investments made by farmers in terms of inputs and late harvesting, which increased the $\mathrm{CO}_{2} \mathrm{e}$ emission of cropping activities, and to higher temperature, which increased anaerobic respiration and $\mathrm{CH}_{4}$ emission (Figure 2).

The $\mathrm{CO}_{2} \mathrm{e}$ emissions of $\mathrm{CH}_{4}$ and $\mathrm{N}_{2} \mathrm{O}$ gases under continuously flooded rice fields were estimated at $102.0 \mathrm{~kg}$ $\mathrm{CH}_{4} \mathrm{ha}^{-1} \mathrm{~d}^{-1}$ and $5.2 \mathrm{~kg} \mathrm{~N}_{2} \mathrm{O} \mathrm{ha}^{-1} \mathrm{~d}^{-1}$, respectively, in the WS and $139.5 \mathrm{~kg} \mathrm{CH}_{4} \mathrm{ha}^{-1} \mathrm{~d}^{-1}$ and $8.2 \mathrm{~kg} \mathrm{~N}_{2} \mathrm{O} \mathrm{ha}^{-1} \mathrm{~d}^{-1}$, respectively, in the DS (Gaihre et al., 2014).

Cropping activities in the DS and WS emitted 1.5 and 1.3 tons $\mathrm{CO}_{2} \mathrm{ha}^{-1}$, respectively (Figures 3 and 4). The group that emitted the highest $\mathrm{CO}_{2} \mathrm{e}$, contributing 1.0-0.8 ton $\mathrm{CO}_{2} \mathrm{ha}^{-1}$, was chemicals (fertilizers and pesticides). Other contributors included fuel consumption of agricultural farm machines, laborers, the production and repair of irrigation structures such as dams and canals, seeds, machinery, and lubricant (Figures 3 and 4).

The use of varieties possessing a combination of the key traits of early maturity and higher grain yield production with drought tolerance could decrease $\mathrm{CO}_{2} \mathrm{e}$ emissions. Early maturity decreased soil $\mathrm{CH}_{4}$ and $\mathrm{N}_{2} \mathrm{O}$ emissions per unit area (ha), production of higher grain yield decreased $\mathrm{CO}_{2} \mathrm{e}$ emission per unit of rice weight (ton), and drought tolerance mitigates the effect of paddy field wetting and drying. The single mid-season drainage system generally tends to decrease $\mathrm{CH}_{4}$ emission up to $46.0 \%$ and increase $\mathrm{N}_{2} \mathrm{O}$ emission up to $3.4 \%$ as compared to continuously flooded paddy fields (Wassmann et al., 2010). 


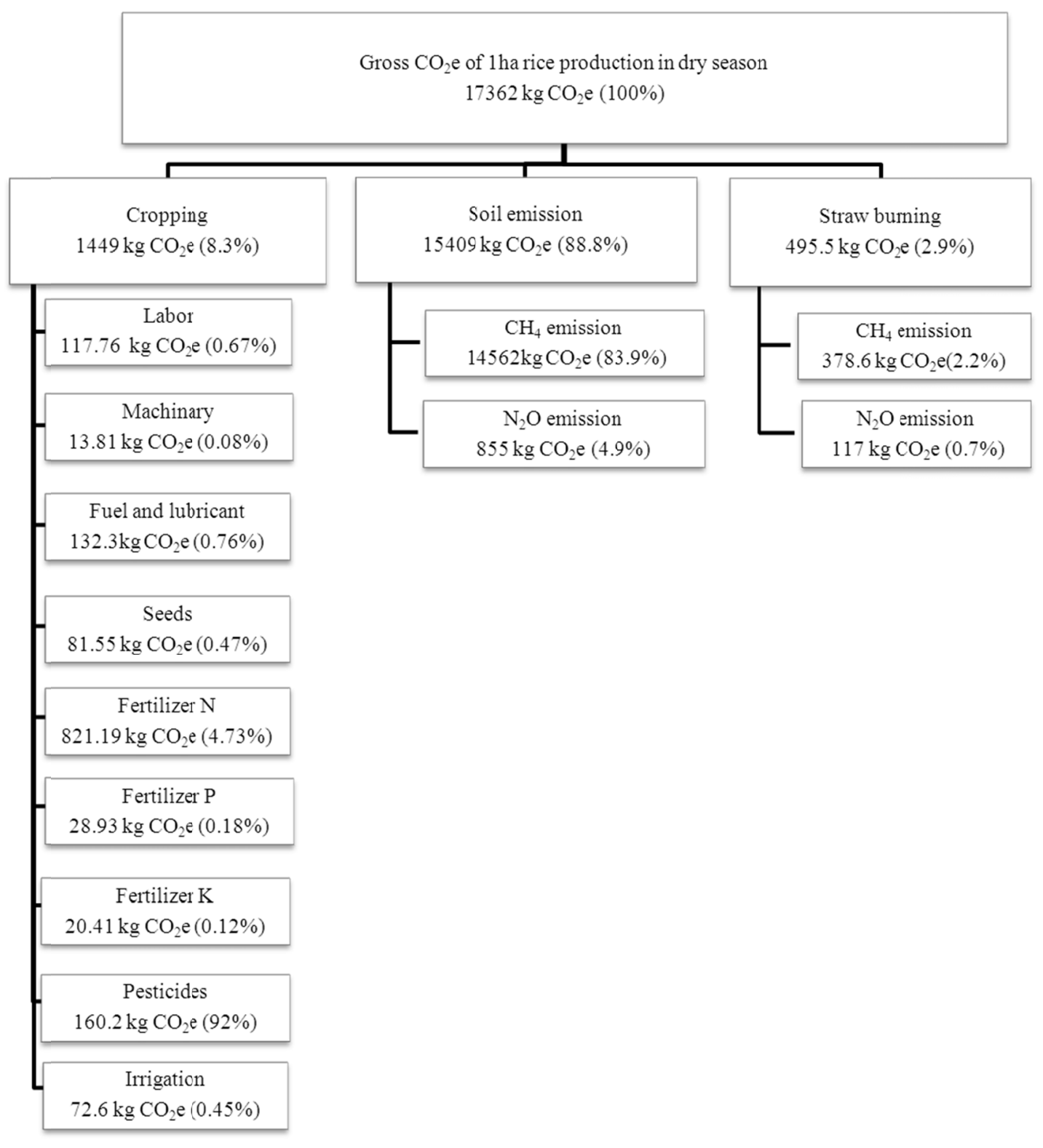

Figure 3. Relative gross $\mathrm{CO}_{2}$ e emission of production over 1 hectare rice field during dry season 


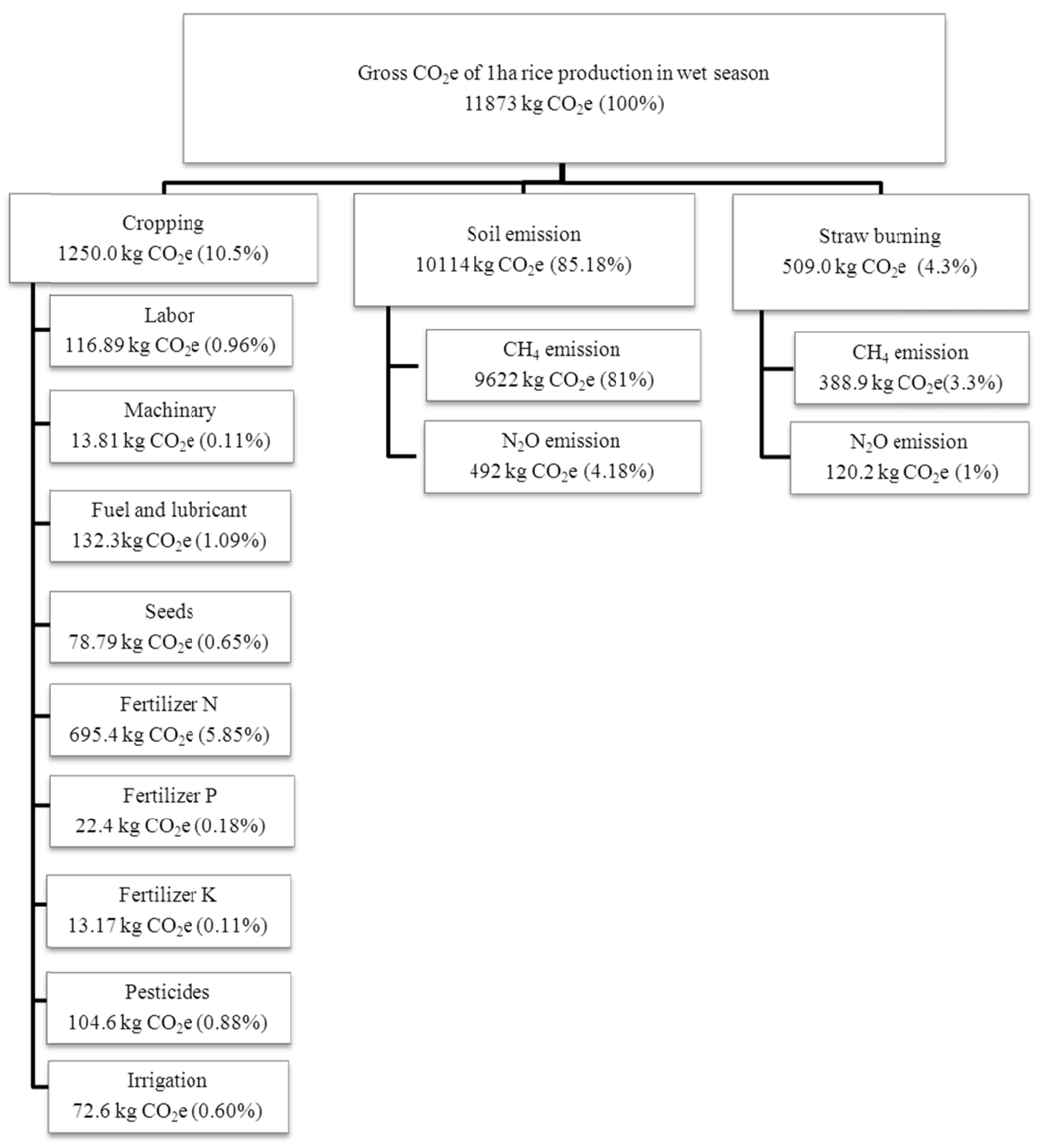

Figure 4. Relative gross $\mathrm{CO}_{2}$ e emission of production over 1 hectare rice field during wet season

The $\mathrm{CO}_{2}$ emission per unit area of yield clearly shows that both GSR2 (2.44 tons/ton) and GSR 8 (2.42 tons/ton) produced a lower $\mathrm{CO}_{2} \mathrm{e}$ average than hybrids (SL9 and SL7) and inbreds (PSBRC11, PSBRC18, and PSBRC216). GSR 2 was found to be significantly different than the hybrid by 0.74 ton/ton $(p<0.001)$ and significantly different than the inbreds by 0.90 ton/ton $(p<0.001)$. GSR 8 was also found to be significantly different from the hybrid by 0.76 ton/ton $(p<0.001)$ and significantly different than the inbred by 0.92 ton/ton $(p$ $<0.001)$. On the other hand, both GSR varieties were not significantly different in $\mathrm{CO}_{2} \mathrm{e}$ emission $(p=0.998)$. Post-production data analysis shows that only GSR 8 and the inbred are significantly different $(p<0.030)$ in terms of $\mathrm{CO}_{2}$ emission at alpha $=5 \%$. The variety GSR 2 had the lowest $\mathrm{CO}_{2}$ emission with an average of 15.23 tons $\mathrm{ha}^{-1}$ among all the varieties, whereas the hybrids produced the highest, with an average of 19.46 tons ha $^{-1}$ from production to post-production. GSR 2 was also found to produce significantly different $\mathrm{CO}_{2} \mathrm{e}$ with an absolute difference of 1.87 tons $^{-1} a^{-1}, 4.22$ tons $^{-1} a^{-}$, and 1.52 tons ha ${ }^{-1}$ from GSR $8(p=0.004)$, the hybrid $(p<$ $0.001)$, and the inbred $(p=0.036)$, respectively. Figure 5 shows that majority of $\mathrm{CO}_{2}$ emission were made during production stage. 
per yield (ton/ton)

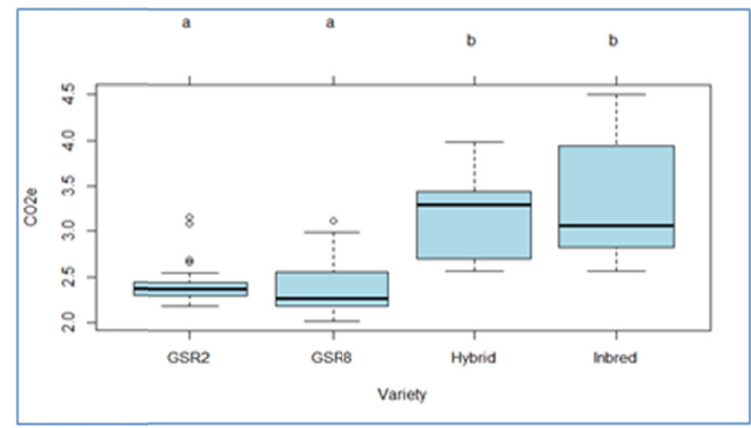

at production (ton/ha)

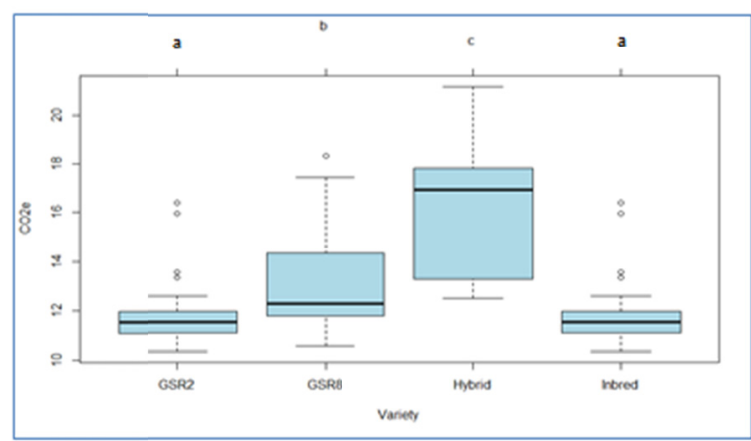

at post-production (ton/ha)

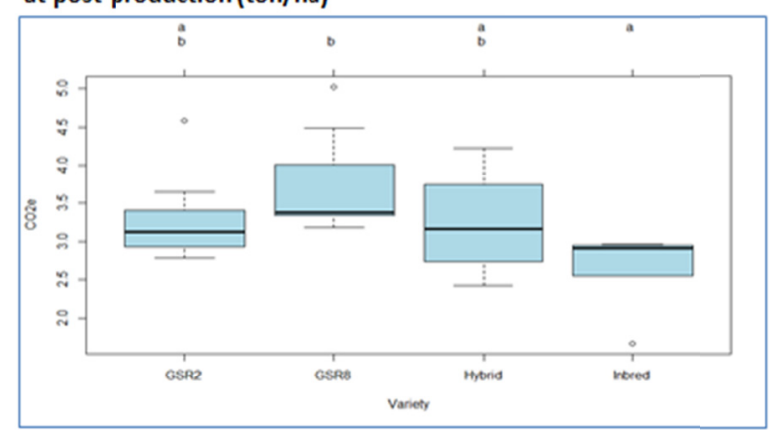

at production to post-production (ton/ha)

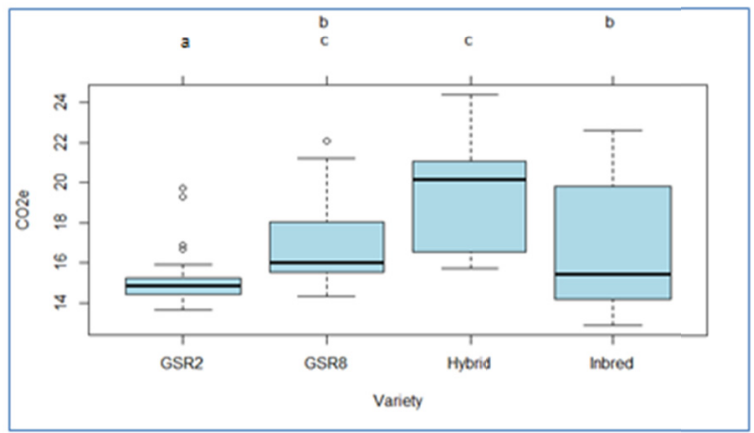

Figure 5. Relative $\mathrm{CO}_{2}$ emission of different rice cultivars per unit area from production to post-production Note. Same letters indicate non-significant differences at $5 \%$ level of significance within each trait.

Like most farmers in the Philippines, the farmers in the study sites in Laguna harvest rice by cutting the mature crop a few inches below the panicles. The harvested parts of the rice crop with panicles are separated from the grains and are mostly burned after complete drying. The average weight of the harvested part of the rice straw, which is often burned after threshing, is estimated at 6.2 tons ha $^{-1}$ (Table 4). Only $90.0 \%$ of the harvested straw is completely burned (IPCC, 1997). Much of the remaining straw in the field is returned to the soil and relatively only a little is used as animal feed. The general estimation for the $\mathrm{CO}_{2} \mathrm{e}$ of $\mathrm{CH}_{4}$ and $\mathrm{N}_{2} \mathrm{O}$ emissions from burning of one hectare of rice straw was 0.5 ton $\mathrm{CO}_{2} \mathrm{ha}^{-1}$.

Table 4. Mean $\mathrm{CO}_{2} \mathrm{e}$ emission $\left(\mathrm{CO}_{2} \mathrm{e}\right.$ in $\left.\mathrm{kg} \mathrm{ha}^{-1}\right)$ due to $\mathrm{CH}_{4}$ and $\mathrm{N}_{2} \mathrm{O}$ emission of straw burning

\begin{tabular}{llllllllll}
\hline & Unit & Balitoc & Coralan & Cambuja & Talangka & Munting Kawayan & Bagum bayan & Oobi & Mean \\
\hline Weight of straw & Ton ha $^{-1}$ & 4.18 & 5.44 & 4.89 & 7.89 & 8.17 & 3.7 & 9.35 & 6.23 \\
$10 \%$ unburnt & Ton ha & 0.42 & 0.54 & 0.489 & 0.79 & 0.82 & 0.37 & 0.94 & 0.624 \\
$90 \%$ burnt straw & Ton ha & 3.76 & 4.9 & 4.40 & 7.10 & 7.35 & 3.33 & 8.42 & 5.61 \\
$\mathrm{CH}_{4}$ emission & $\mathrm{kg} \mathrm{ha}^{-1}$ & 10.16 & 13.22 & 11.88 & 19.17 & 19.85 & 8.99 & 22.72 & 15.14 \\
$\mathrm{~N}_{2} \mathrm{O}$ emission & $\mathrm{kg} \mathrm{ha}^{-1}$ & 0.26 & 0.34 & 0.31 & 0.50 & 0.51 & 0.23 & 0.59 & 0.39 \\
$\mathrm{CO}_{2}$ eq of CH & $\mathrm{kg} \mathrm{ha}_{4}^{-1}$ & 253.94 & 330.48 & 297.07 & 479.32 & 496.33 & 224.78 & 568 & 378.56 \\
$\mathrm{CO}_{2}$ eq of $\mathrm{N}_{2} \mathrm{O}$ & $\mathrm{kg} \mathrm{ha}^{-1}$ & 78.47 & 102.13 & 91.80 & 148.13 & 153.38 & 69.46 & 175.5 & 116.99 \\
\hdashline $\mathrm{Total} \mathrm{CO}_{2}$ eq & $\mathrm{kg} \mathrm{ha}^{-1}$ & 332.41 & 432.61 & 388.87 & 627.44 & 649.71 & 294.24 & 743.6 & 495.55 \\
\hline
\end{tabular}

\subsection{Yield}

In this study, rice crop production in some locations in the DS was affected by water shortages and diseases like tungro. Due to severe drought in some locations, farmers were not able to harvest any yields while some were not able to plant at all. However, the average grain yield production in the WS (6.55 tons/ha) and DS (5.50 tons/ha) were not significantly different $(p=0.07)$. 
The grain yield evaluation of the different rice varieties (Table 5) during the WS and DS in Laguna showed significant differences between GSR8 and inbred varieties $(p<0.05)$. GSR8 produced the highest grain yield with an average of 7.0 tons $\mathrm{ha}^{-1}$. In contrast, the difference in average grain yield between GSR2 and hybrid varieties at 6.3 and 6.1 tons ha $^{-1}$, respectively, was not significant. The minimum grain yields produced by inbred varieties were estimated at 5.0 tons $\mathrm{ha}^{-1}$.

The average grain yields of the two GSR cultivars planted in the mountainous areas of Barangay Oobi and Munting Kawayan in the town of Majayjay were significantly different $(p<0.05)$ from the grain yields obtained in other locations (Balitoc, Cambuja, Coralan, Talangka, and Bagumbayan). For the GSR cultivars, the average yields in the mountainous areas (Oobi and Munting Kawayan) were estimated at 9.0 and 8.5 tons ha ${ }^{-1}$, respectively, for GSR8, and 7.0 and 8.6 tons ha ${ }^{-1}$, respectively, for GSR2. Inbred varieties produced 50.0-60.0\% lower yield than GSR varieties. In these two barangays, both GSR varieties recorded higher yields in the WS than in the DS. Hybrid varieties were not planted in Oobi and Munting Kawayan. The average yield of the GSR cultivars showed no significant difference in all other locations (Balitoc, Cambuja, Coralan, Talangka, and Bagumbayan).

Table 5. Mean grain yield (ton $\mathrm{ha}^{-1}$ ) of GSR and non-GSR varieties at 7 different locations in Laguna, Philippines during the dry and wet seasons

\begin{tabular}{|c|c|c|c|c|c|c|c|c|c|c|}
\hline \multicolumn{3}{|c|}{ Entries/season } & \multirow{2}{*}{$\begin{array}{l}\text { Bagumbayan } \\
5.75\end{array}$} & \multirow{2}{*}{$\begin{array}{l}\text { Cambuja } \\
\text { NP }\end{array}$} & \multirow{2}{*}{$\begin{array}{l}\text { Coralan } \\
6.5\end{array}$} & \multirow{2}{*}{$\begin{array}{l}\text { Balitoc } \\
5.8\end{array}$} & \multirow{2}{*}{$\begin{array}{l}\text { Munting kawayan } \\
7.21\end{array}$} & \multirow{2}{*}{$\begin{array}{l}\text { Oobi } \\
7.54\end{array}$} & \multirow{2}{*}{$\begin{array}{l}\text { Talangka } \\
7.78\end{array}$} & \multirow{2}{*}{$\begin{array}{l}\text { Mean } \\
6.76\end{array}$} \\
\hline GSR8 & DS & $\left(\right.$ Ton ha $\left.{ }^{-1}\right)$ & & & & & & & & \\
\hline & WS & $\left(\right.$ Ton ha $\left.{ }^{-1}\right)$ & 6.75 & 6.66 & 6.2 & 6.23 & 9.73 & 10.36 & 4.95 & 7.27 \\
\hline Average & AS & $\left(\right.$ Ton ha $\left.{ }^{-1}\right)$ & 6.25 & 6.66 & 6.35 & 6.15 & 8.47 & 8.95 & 6.36 & $7.01 \mathrm{a}$ \\
\hline \multirow[t]{2}{*}{ GSR2 } & DS & $\left(\right.$ Ton ha $\left.{ }^{-1}\right)$ & NP & $\mathrm{NP}$ & NP & 5.08 & NP & 5.93 & 5.01 & 5.34 \\
\hline & WS & $\left(\right.$ Ton ha $\left.{ }^{-1}\right)$ & 5.97 & 5.57 & 5.89 & 5.68 & 8.64 & 8.13 & 5.5 & 6.48 \\
\hline Average & & $\left(\right.$ Ton ha $\left.{ }^{-1}\right)$ & 5.97 & 5.57 & 5.89 & 5.38 & 8.64 & 7.03 & 5.25 & $6.25 \mathrm{ab}$ \\
\hline \multirow[t]{2}{*}{ Hybrid } & DS & $\left(\right.$ Ton ha $\left.{ }^{-1}\right)$ & 4.57 & 6.98 & 4.42 & 7.96 & NP & NP & NP & 5.98 \\
\hline & WS & $\left(\right.$ Ton ha $\left.{ }^{-1}\right)$ & NP & 5.41 & 6.74 & NP & NP & NP & NP & 6.08 \\
\hline Average & $\mathrm{AS}$ & $\left(\right.$ Ton ha $\left.{ }^{-1}\right)$ & 4.57 & 6.2 & 5.58 & 7.96 & - & - & - & $6.12 \mathrm{ab}$ \\
\hline \multirow[t]{2}{*}{ Inbred } & DS & $\left(\right.$ Ton ha $\left.{ }^{-1}\right)$ & NP & 4.72 & 5.58 & 5.47 & 3.35 & 3.16 & 5.52 & 4.63 \\
\hline & WS & $\left(\right.$ Ton ha $\left.{ }^{-1}\right)$ & NP & 6.69 & NP & NP & 6.26 & 3.13 & NP & 5.36 \\
\hline Average & AS & $\left(\right.$ Ton ha $\left.{ }^{-1}\right)$ & & 5.71 & 5.58 & 5.47 & 4.81 & 3.15 & 5.52 & $5.02 \mathrm{~b}$ \\
\hline Mean & & $\left(\right.$ Ton ha $\left.{ }^{-1}\right)$ & 5.60 & 6.04 & 5.85 & 6.24 & 7.31 & 6.38 & 5.71 & 6.10 \\
\hline
\end{tabular}

Note. Same letters indicate no significant difference at $5 \%$ level of significance. DS $=$ Dry Season; WS $=$ Wet Season; AS = Across Season; NP = Not Planted.

\subsection{The $\mathrm{CO}_{2}$ e Emission of Rice at Post-Production}

The average $\mathrm{CO}_{2} \mathrm{e}$ emission of 1 ton unmilled rice at post-production (Table 6) in the WS and DS was estimated at 0.53 ton $\mathrm{CO}_{2}$ ton ${ }^{-1}$ of rice. Based on milling recovery $(59.0 \%)$, the average $\mathrm{CO}_{2} \mathrm{e}$ emission of 1 ton milled rice at post-production level in the WS and DS was estimated at 0.8 ton $\mathrm{CO}_{2} \operatorname{ton}^{-1}$ of milled rice. Cooking and transporting to retailer contributed $66.7 \%$ and $27.3 \%$, respectively, to the total $\mathrm{CO}_{2} \mathrm{e}$ emission at post-production, whereas drying, milling, storage, and retailing contributed 3.6\%.

The $\mathrm{CO}_{2} \mathrm{e}$ emission of post-production from 1 hectare of rice was directly related to the average yield of each variety, increasing as the yield increased (Figure 5). The highest $\mathrm{CO}_{2} \mathrm{e}$ emission of post-production, which was produced by GSR8 $\left(3.75\right.$ ton $\left.\mathrm{CO}_{2} \mathrm{e} \mathrm{ha}^{-1}\right)$ was significantly higher $(\mathrm{p}=0.03)$ than that by the inbred varieties $(2.7$ ton $\mathrm{CO}_{2} \mathrm{e} \mathrm{ha} \mathrm{h}^{-1}$ ). Between GSR2 (3.31 ton $\left.\mathrm{CO}_{2} \mathrm{e} \mathrm{ha}{ }^{-1}\right)$ and the hybrid varieties $\left(3.24\right.$ ton $\left.\mathrm{CO}_{2} \mathrm{e} \mathrm{ha}^{-1}\right), \mathrm{CO}_{2} \mathrm{e}$ emissions were not significantly different $(p=0.998)$ and were comparable to GSR8 $(\mathrm{p}=0.581)$ (Figure 5$)$. 
Table 6. Mean $\mathrm{CO}_{2} \mathrm{e}$ emission of 1 ton of rice under post-production chain across wet and dry seasons

\begin{tabular}{|c|c|c|c|c|c|c|c|c|}
\hline & Transport to miller & Sun drying & Milling & Storage & Transport to retailer & Retailer & Cooking & Total \\
\hline & \multicolumn{8}{|c|}{ 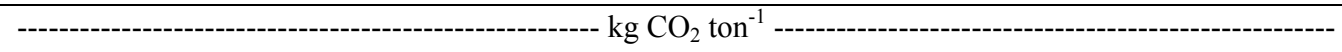 } \\
\hline Labor & 0.681 & 3.642 & 2.337 & 0.537 & 0.402 & 4.566 & 201.47 & 213.636 \\
\hline Machinery & 0.128 & & 1.65 & & 0.076 & & 0.0025 & 1.856 \\
\hline Storage & & & 0.503 & 0.205 & & 0.0045 & & 0.713 \\
\hline Fuel & 17.533 & & 15.186 & & 216 & & 328.91 & 577.63 \\
\hline Lubricant & 0.706 & & 0.281 & & 0.417 & & & 1.405 \\
\hline Total & 19.05 & 3.64 & 19.96 & 0.74 & 216.90 & 4.57 & 530.38 & 795.24 \\
\hline$\%$ & $2.4 \%$ & $0.46 \%$ & $2.51 \%$ & $0.09 \%$ & $27.3 \%$ & $.57 \%$ & $66.7 \%$ & \\
\hline
\end{tabular}

Note. $\mathrm{CO}_{2} \mathrm{e}$ emission of transportation to retailer was estimated at $1.8 \mathrm{~kg} \mathrm{CO}_{2} \operatorname{ton}^{-1} \mathrm{~km}^{-1}$ with the rice mill situated at a total distance of $120 \mathrm{~km}$.

\subsection{Social Cost of Carbon}

In this study, SCC was estimated at $\$ 40 \mathrm{t}^{-1}$ of $\mathrm{CO}_{2}$. In 1 ha of rice production in Laguna, where the average gross emission was estimated at 17.85 tons $\mathrm{CO}_{2} \mathrm{e}$, the SCC per hectare of rice field was estimated at $\$ 714$.

The average SCC per ton of rice was estimated at \$119. The SCC per ton of GSR8, GSR2, hybrid varieties (SL9 and SL7), and inbred varieties (PSBRC11, PSBRC18, and PSBRC216) were estimated at $\$ 96, \$ 96, \$ 128$, and $\$ 132$ per ton, respectively. The two GSR varieties recorded the lowest SCC per ton of rice weight, with GSR8 giving an impressive lowest SCC with almost over $37 \%$ reduction as compared to the elite inbred rice varieties.

\section{Discussion}

\subsection{Low $\mathrm{CO}_{2}$ e Emission Varieties}

The average $\mathrm{CO}_{2}$ e emission in the production level of rice was equivalent to $82 \%\left(14.6\right.$ tons $\left.\mathrm{CO}_{2} \mathrm{ha}^{-1}\right)$ of the total rice $\mathrm{CO}_{2} \mathrm{e}$ emission from production to post-production. To decrease the $\mathrm{CO}_{2} \mathrm{e}$ emission per unit of rice grain yield, farmers can use varieties with higher grain yield production per unit area. As shown in this study, GSR8 produced a significantly higher grain yield $\left(7.0\right.$ tons ha $\left.{ }^{-1}\right)$ than the other inbred varieties $\left(5.0\right.$ tons ha $\left.\mathrm{a}^{-1}\right)$, at the same time producing the lowest $\mathrm{CO}_{2} \mathrm{e}$ emission per ton of rice production. Farmers can also use varieties with shorter growth duration as shown by GSR2, which was given significantly $(p<0.05)$ the shortest growth duration in an average of 13.1 weeks (Figure 5). The $\mathrm{CO}_{2} \mathrm{e}$ emission at production level of GSR2 (11.9 ton $\mathrm{CO}_{2} \mathrm{e}$ $\mathrm{ha}^{-1}$ ) was significantly $(\mathrm{p}<0.05)$ lower than that of GSR8 $\left(13.4\right.$ ton $\left.\mathrm{CO}_{2} \mathrm{e} \mathrm{ha}^{-1}\right)$, inbred $\left(14.1\right.$ ton $\left.\mathrm{CO}_{2} \mathrm{e} \mathrm{ha} \mathrm{h}^{-1}\right)$, and hybrid varieties (16.2 ton $\mathrm{CO}_{2} \mathrm{e} \mathrm{ha}^{-1}$ ) (Figure 5). GSR8 planted in the mountainous area (town of Majayjay) produced 1.5-2.0 tons ha ${ }^{-1}$ higher yield than its average yield in other locations (Table 5). The combination of the two traits of early maturity and high yield production is the key to significantly decrease rice $\mathrm{CO}_{2} \mathrm{e}$ emission. The yield production of GSR2 (6.3 tons ha ${ }^{-1}$ ) was not significantly different from that of GSR8 (7.0 tons ha ${ }^{-1}$ ) (Figure 5) but, in terms of growth duration, GSR2 was one week shorter than GSR8. Another approach to drastically decrease GHG emissions per unit of rice grain yield is to practice the alternate wetting and drying of paddy soils; but this is largely more applicable to drought-tolerant and aerobic rice varieties. GSR2 and GSR8 are drought-tolerant rice cultivars (Marcaida et al., 2014; Ali et al., 2013) and are therefore highly suitable for alternate wetting and drying conditions.

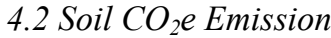

The $\mathrm{CO}_{2}$ e of $\mathrm{CH}_{4}$ emissions from saturated soil accounted for $81-84 \%$ of the $\mathrm{CO}_{2}$ e emission of rice at production level (Figures 3 and 4). The challenge is how to reduce $\mathrm{CH}_{4}$ emissions, especially in flooded paddy soils. Single mid-season drainage in flooded paddy soils generally tends to decrease $\mathrm{CH}_{4}$ emission up to $46.0 \%$ (Wassmann et al., 2010). Interestingly, in this study, farmers in Barangay Talangka in the town of Sta. Maria were experiencing severe water shortage, which led to several rounds of mid-season drainage. Drought-tolerant rice varieties, such as GSR2 and GSR8, were able to persist in this condition (Ali et al., 2013).

The $\mathrm{CO}_{2} \mathrm{e}$ emission of $\mathrm{N}_{2} \mathrm{O}$ was estimated to be about $4-5 \%$ of the total $\mathrm{CO}_{2} \mathrm{e}$ emission at production level. Approximately $1-5 \%$ of the nitrogen content of $\mathrm{N}$ fertilizer is released as $\mathrm{N}_{2} \mathrm{O}$ (Berners-Lee, 2010). Under continuously flooded rice field conditions, the low concentration of oxygen in the soil tends to decrease $\mathrm{N}_{2} \mathrm{O}$ emission. The peak emissions were observed after final drainage, when the concentration of oxygen in the soil increased (Gaihre et al., 2014). Gaihre et al. (2014) reported that the consumption of 80 and $120 \mathrm{~kg}$ nitrogen content of $\mathrm{N}$ fertilizer in the WS and DS, respectively, emitted 2.1 and $3.3 \mathrm{~kg} \mathrm{~N}_{2} \mathrm{O}$ per hectare or 1.3 and $2.1 \mathrm{~kg}$ 
$\mathrm{N}$ per hectare. Furthermore, they found that the average $\mathrm{N}_{2} \mathrm{O}$ emission from rice fields was estimated at $1.7 \%$ of the consumed nitrogen content of $\mathrm{N}$ fertilizer. However, single mid-season drainage generally tends to increase $\mathrm{N}_{2} \mathrm{O}$ emission up to $3.4 \%$ (Wassmann et al., 2010).

Development and use of early-maturing rice varieties decreased the $\mathrm{CO}_{2} \mathrm{e}$ emission per unit area at production level (Figure 5). The average growth duration from transplanting to harvesting was 13.1 weeks for GSR2 and 14 weeks for GSR8. For inbred and hybrid varieties, an average duration of 14.2 and 15.4 weeks was observed.

\subsection{Straw Burning and Straw Anaerobic Decomposition}

In the Philippines, the present farming practice involves the burning of about $60-70 \%$ of the rice straw after threshing. Some farmers also do not cut the rice straw properly, thereby leaving about $30-40 \%$ of the straw in the field. This rice straw biomass gets incorporated into the soil during the following cropping season, resulting in an increase in anaerobic decomposition and emission of $\mathrm{CH}_{4}$.

Some scientists believe that the $\mathrm{CO}_{2}$ released during straw burning will be reabsorbed by photosynthesis in the next cropping season and does not actually account for rice $\mathrm{CO}_{2} \mathrm{e}$ emission (Bockel \& Tinlot, 2012). Their studies have mostly focused on the $\mathrm{CO}_{2}$ taken up, which is returned to the atmosphere in the form of $\mathrm{CH}_{4}$ and $\mathrm{N}_{2} \mathrm{O}$. The $\mathrm{CH}_{4}$ and $\mathrm{N}_{2} \mathrm{O}$ emission from burning of straw contributes 0.38 and 0.12 ton $\mathrm{CO}_{2} \mathrm{e}$ ha ${ }^{-1}$, respectively (Table 4).

The mitigation strategy is to cut the straw as close to the ground level as possible and to gather the straw after threshing. The gathered straw can be used as a fiber source or as particleboard. Straw particleboards have broad applications owing to their rigidness, strength, and lower costs compared to plywood (Jeon et al., 2011). Paper can also be successfully manufactured from cereal straw. Numerous private enterprises for straw and pulp are now established worldwide. In fact, one of the more successful Philippine handmade rice straw paper manufacturers is in Los Baños, Laguna (IRRI, 2008).

Given these potentials, local governments and agricultural agencies should implement local ordinances and farm policies that strictly prohibit rice straw burning. Burning could be allowed, but only for special purposes such as for effective pest and disease control. A practice that may potentially mitigate GHG emissions is straw removal through baling, which could reduce GHG emissions to as much as 30\% (Garnache et al., 2011). The treatment of rice straw as feedstock for heifer or cattle and spreading of decomposed manure in the same paddy where they were harvested maintains the soil fertility balance while reducing $\mathrm{CH}_{4}$ emission. Rice straw is rich in polysaccharides and has a high lignin and silica content but it is poor in protein. To improve the protein content of rice straw, chemical and biological treatments can be used. Urea or $\mathrm{NH}_{3}$ is an example of a chemical treatment, which currently seems to be more practical for on-farm use. Ligninolytic fungi (white-rot fungi), with their extracellular ligninolytic enzymes, are used as a biological treatment for rice straw (Sarnklong et al., 2010).

\subsection{Chemical and Fertilizer Requirements}

Consumption of pesticides and fertilizers contributed $6 \%$ to $7 \%$ of the total $\mathrm{CO}_{2}$ e emission at production level (Figures 3 and 4). The development of cultivars with resistance to biotic stresses (pest and disease) and have a low requirement for fertilizers has been seen to decrease the $\mathrm{CO}_{2} \mathrm{e}$ emission of cropping. Interestingly, the high-yielding and short-duration GSR varieties also possess tolerance for multiple biotic (blast, bacterial leaf blight, and brown planthopper) and abiotic (less irrigation, drought, and lower fertilizer inputs) stresses (Ali et al., 2013). This also makes the GSR varieties adaptable to organic farming, where chemical fertilizers and pesticides are not used at all. However, to maximise the grain yield of any variety, it is always recommended to follow site-specific nutrient management.

\subsection{Post-Production Emissions}

The average $\mathrm{CO}_{2} \mathrm{e}$ emission at post-production level of rice was equivalent to $18 \%$ (3.2 tons $\left.\mathrm{CO}_{2} \mathrm{ha}^{-1}\right)$ of the total rice $\mathrm{CO}_{2} \mathrm{e}$ emission from production to post-production. Cooking and transporting of rice to retailer contributed $66.7 \%$ and $27.3 \%$ of the total $\mathrm{CO}_{2} \mathrm{e}$ emission at post-production level, respectively.

\subsection{Social Cost of Carbon}

The average SCC per ton of rice was estimated at $\$ 119$. The SCC rates per ton of GSR8, GSR2, hybrid varieties (SL9 and SL7), and inbred varieties (RC11, RC18 and RC216) were estimated at $\$ 96, \$ 96, \$ 128$, and $\$ 132$ per ton, respectively. This clearly shows that the $\mathrm{CO}_{2} \mathrm{e}$ emission of the newly released GSR cultivars, GSR8 and GSR2, were the lowest among the seven varieties studied. However, data on SCC on a per day basis could be effective in understanding the importance of early duration, high-yielding, and drought-tolerant rice cultivars in the current environmental conditions. Drought-tolerant rice varieties need to perform exceedingly well under 
both irrigated and drought conditions (Man et al., 2014) as several rounds of mid-season drainage could be possible without losing grain yield while drastically reducing $\mathrm{CH}_{4}$ emissions from flooded paddy fields. This could further reduce the SCC and provide the basis for developing future rice varieties with low $\mathrm{CO}_{2} \mathrm{e}$ emission.

\section{Conclusions}

The mean of the gross $\mathrm{CO}_{2} \mathrm{e}$ emission of rice per unit area in the dry and wet seasons from production to post-production was estimated at 17.9 tons $\mathrm{CO}_{2} \mathrm{ha}^{-1}$ or 2.98 tons $\mathrm{CO}_{2} \operatorname{ton}^{-1}$ of rice. The contributors to this total are as follows: soil emission (72\%), the use of fertilizers and pesticides $(5 \%)$, burning of rice straw (3\%), and post-production (18\%).

Using early-maturing varieties and increasing the yield production per unit area are the key factors to decrease the $\mathrm{CO}_{2} \mathrm{e}$ emission per unit of rice weight. The $\mathrm{CO}_{2} \mathrm{e}$ emission per unit grain yield from GSR8 and GSR2 was $37.0 \%$, which was significantly lower than that from the popular inbred varieties. GSR8 gave the highest grain yield production and emitted 5.0-37.0\% lesser $\mathrm{CO}_{2} \mathrm{e}$ emission per unit of rice weight than other cultivars. The grain yield production of GSR2 and hybrid varieties (SL9 and SL7) was not significantly different. However, due to its early maturity trait, the $\mathrm{CO}_{2} \mathrm{e}$ emission of GSR2 was $33.0 \%$ lower than that of the hybrid varieties. The inbred varieties produced lower yields but also produced the highest $\mathrm{CO}_{2} \mathrm{e}$ emission per unit of rice weight.

The average social cost of carbon (SCC) per ton of rice was estimated at $\$ 119$. The SCC decreased in varieties with lower $\mathrm{CO}_{2} \mathrm{e}$ emissions. In this study, GSR varieties with higher grain yield and shorter growth duration had the lowest $\mathrm{CO}_{2} \mathrm{e}$ emission, that is, the SCC in GSR8 and GSR2 was 37.5\% less than the SCC of the elite inbred varieties tested. Deployment of low $\mathrm{CO}_{2} \mathrm{e}$ emission varieties such as GSR 8 (NSIC Rc 480) and GSR 2 (NSIC Rc 434) on a large scale could be highly beneficial in reducing the impact of climate change, but this needs to be augmented with proper crop management techniques such as alternate wetting and drying.

\section{References}

Ali, J., Xu, J. L., Gao, Y. M., Fontanilla, M., \& Li, Z. K. (2013). Breeding for yield potential and enhanced productivity across different rice ecologies through Green Super Rice (GSR) breeding strategy. In K. Muralidharan, \& E. A. Siddiq (Eds.), International Dialogue on Perception and Prospects of Designer Rice (pp. 60-68). Society for the Advancement of Rice Research, Directorate of Rice Research, Hyderabad, India.

Anoopa, P. S., Scaria, D., Nithya, N. S., \& Prajitha, M. (2007). Energy consumption benchmark studies on parboiled rice cooking in Kerala. Kerala, India: Energy Management Centre, Thiruvananthapuram.

Batjes, N.H. (1996). Total carbon and nitrogen in the soils of the world. European Journal of Soil Science, 47, 151-163. https://doi.org/10.1111/j.1365-2389.1996.tb01386.x

Berners-Lee, M. (2010). How bad are bananas? The carbon footprint of everything. Vancouver, Canada: Greystone Books, D\&M Publishers Inc.

Bockel, L., \& Tinlot, M. (2012). An application to the accelerated food security project in Tanzania. Ex Act software for carbon -balance analysis of investment projects. FAO.

Chang, C., Liu, C., \& Tseng, P. (2013). Emissions inventory for rice straw open burning in Taiwan based on burned area classification and mapping using Formosat-2 Satellite imagery. Aerosol and Air Quality Research, 13, 474-487. https://doi.org/10.4209/aaqr.2012.06.0150

Cummins, S. (2006). Glossary of climate change terms (Vol. 13, pp. 48-60). US Environmental Protection Agency.

EIA (United States Energy Information Administration). (2013). Retrieved from http://www.eia.gov/ environment/emissions/co2_vol_mass.cfm

FAO. (2009). Retrieved from http://www.fao.org/fileadmin/templates/wsfs/docs/expert_paper/How_to_Feed_ the_World_in_2050.pdf

Gaihre, Y. K., Tirol-Padrel, A., Wassmann, R., Aquino, E., Pangga, G. V., \& Sta Cruz, P. (2014). Seasonal assessment of greenhouse gas emissions from irrigated lowland rice fields under infrared warming. Agriculture, Ecosystems and Environment, 184(1), 88-100. https://doi.org/10.1016/j.agee.2013.11.024

Garnache, C., Rosen-Molina, J., \& Sumner, A. (2011). Economics of carbon credits from voluntary practices on rice farms in the Sacramento valley. University of California Agricultural Issues Center. 
Gowda, V., Henry, A,. Vadez, V,. Shashidhar, H., \& Serraj, R. (2012). Water uptake dynamics under progressive drought stress in diverse accessions of the Oryza SNP panel of rice (Oryza sativa). Functional Plant Biology, 39(5), 402-411. https://doi.org/10.1071/FP12015

Hastoe Housing Association. (2010). Sustainable homes: Embodied energy in residential property development, a guide for registered social landlords. Teddington, UK.

Hossain, M., \& Park, K. (2012). Exploiting potentials from interdisciplinary perspectives with reference to global atmosphere and biomass burning management. Aerosol and Air Quality Research, 12, 123-132.

IPCC (Intergovernmental Panel on Climate Change). (1997). In J. T. Houghton, L. G. Meira Filho, B. Lim, K. Tréanton, I. Mamaty, Y. Bonduki, D. J. Griggs, \& B. A. Callander (Eds), Revised 1996 IPCC Guidelines for National Greenhouse Gas Inventories (Volumes 1, 2 and 3). IPCC/OECD/IEA, Paris, France.

IPCC (Intergovernmental Panel on Climate Change). (2006). In H. S. Eggleston, L. Buendia, K. Miwa, T. Ngara, \& K. Tanabe (Eds.), 2006 IPCC Guidelines for National Greenhouse Gas Inventories. Prepared by the National Greenhouse Gas Inventories Programme. Japan: IGES.

IPCC (Intergovernmental Panel on Climate Change). (2007). Climate Change 2007: The Physical Science Basis. Cambridge, UK: Cambridge University Press.

IRRI (International Rice Research Institute). (2008). Making Paper from Rice Straw (p. 27). Manila, Philippines: The International Rice Research Institute (IRRI).

IRRI (International Rice Research Institute). (2013). Rice Knowledge Bank. Manila, Philippines: The International Rice Research Institute (IRRI). Retrieved from http://www.knowledgebank.irri.org/ $\mathrm{rkb} /$ harvesting-costs.html

IRRI (International Rice Research Institute). (2017). Plant Breeding Tools. Manila, Philippines: The International Rice Research Institute (IRRI). Retrieved from http://bbi.irri.org/products

Jeon, J., Lee, J., \& Kim, S. (2011). Soybean-based green adhesive for environment-friendly furniture material. Journal of the Korea Furniture Society, 22(3), 174-182.

Kagi, T., Wettstein, D., \& Dinkel, F. (2010). Comparing rice products: Confidence intervals as a solution to avoid wrong conclusions in communicating carbon footprints. Proceedings of LCA food 2010 (Vol. 1, pp. 229-233). Bari, Italy.

Marcaida, M., Li, T., Angeles, O., Evangelista, G., Fontanilla, M. Xu, J., ... Ali, J. (2014). Biomass accumulation and partitioning of newly developed Green Super Rice (GSR) cultivars under drought stress during there productive stage. Field Crops Research, 162, 30-38. https://doi.org/10.1016/j.fcr.2014.03.013

Mclaughlin, N. B., Hiba, A., Wall, G. J., \& King, D. J. (2000). Comparison of energy inputs for inorganic fertilizer and manure based corn production. Canadian Agricultural Engineering, 42(1), 9-17.

Mendoza, T. (2014). Reducing the carbon footprint of sugar production in the Philippines. Journal of Agricultural Technology, 10(1), 289-308.

Nalley, L., Popp, M., \& Fortin, C. (2011). The impact of reducing greenhouse gas emissions in crop agriculture: A spatial and production-level analysis. Agricultural and Resource Economics Review, 40(1), 63-80. https://doi.org/10.1017/S1068280500004524

Ozkan, B., Akcaoz, H., \& Fert, C. (2004). Energy input-output analysis in Turkish agriculture. Renewable Energy, 29, 39-51. https://doi.org/10.1016/S0960-1481(03)00135-6

Pimentel, D. (1980). Hand book of energy utilization in agriculture (p. 387). Boca Raton, FL: CRC Press.Inc.

Pimentel, D., \& Pimentel, M. (2008). Food, energy and society (pp. 108-112). Boca Raton, FL: CRC Press Inc.

Popkiewicz, M. (2014). If growth of $\mathrm{CO}_{2}$ concentration causes only logarithmic temperature increase-Why worry? Skeptical Science. Retrieved from http://www.skepticalscience.com/CO2-emissions-vs-Temperature -growth.html

Sarnklong, C., Cone, J., Pellikaan, W., \& Hendriks, H. (2010). Utilization of rice straw and different treatments to improve its feed value for ruminants: A review. Asian-Aust. J. Anim. Sci., 23(5), 680-692. https://doi.org/10.5713/ajas.2010.80619

Suralta, R. (2015). Functional roles of constitutive root system development in maintaining higher water use and grain yield under post flowering drought stress in hybrid rice. The Philippine Agricultural Scientist, 98(1), 399-406. 
Taghavi, S., \& Mendoza, T. (2001). Energy Accounting of Irrigated Wheat Production to Post Production (Baking Bread) in Doroodzan, Fars Province, Iran. Annals of Tropical Research, 33(2), 1-18.

Tollefson, J. (2015). Social cost of carbon emissions in spotlight. Nature International Weekly Journal of Science. https://doi.org/10.1038/nature.2015.18789

Traas, C. (2012). A model in sustainable development. Retrieved from file:///E:/IRRI/refernces/carbonfootprint books/Newfolder/Contraasenergy-use-in-agriculture.pdf

Tubiello, F., Salvatore, M., Rossi, S., Ferrara, A., Fitton, N., \& Smith, P. (2013). The FAOSTAT database of greenhouse gas emissions from agriculture. Bristol UK: IOP Publishing Ltd.

Wassmann, R., Nelson, G. C., Peng, S. B., Sumfleth, K., Jagadish, S. V. K., Hosen, Y., \& Rosegrant, M. W. (2010). Rice and global climate change (pp. 411-432). Los Baños, Philippines: International Rice Research Institute (IRRI).

\section{Copyrights}

Copyright for this article is retained by the author(s), with first publication rights granted to the journal.

This is an open-access article distributed under the terms and conditions of the Creative Commons Attribution license (http://creativecommons.org/licenses/by/4.0/). 